\title{
Significance of Changing Korean Youth Subculture Styles
}

\author{
Ji soo Ha \\ Department of Clothing and Textiles, Seoul National University \\ San 56-1 Sillim-dong Gwanak-gu, Seoul (151-742), South Korea \\ Tel: 82-2-880-1453Ｅ-mail: jisooha@snu.ac.kr \\ Judy Park (Corresponding author) \\ Department of Clothing and Textiles, Seoul National University \\ 4-405 Chunghwa Apt. Itaewon-dong Yongsan-gu, Seoul (140-731), South Korea \\ Tel: 82-10-8651-5134Ｅ-mail: judy5134@gmail.com
}

Funding disclosure: This study was partially supported by the Research Fund from the Research Institute of Human Ecology of Seoul National University.

\begin{abstract}
Subcultures are cultures formed by a social minority group that does not belong to the mainstream, and youth subcultures are subcultures specifically of youths. Youth subcultures have distinct clothing styles that differentiate them from popular culture and through which they express their values and individuality. Korea has a short history of subcultures, but it has quickly formed numerous unique subcultures influenced both by existing subcultures of Euro-America and Korean society. The purpose of this research was to examine Korean youth subculture styles in terms of how they have evolved in a short period of time and how they have been affected by foreign and domestic elements. It provides insight on the symbolization of Korean youth subculture styles and how the changing styles reflect the state of mind and values of Korean youths today.
\end{abstract}

Keywords: Korea, Youth, Subculture, Style

\section{Introduction}

Korean youth subculture style has always been and still is today a method for young people to express identity. However, even though Korea and Japan, for example, are neighboring countries with many similarities such as conservative traditional Eastern values and rapid economic and cultural development, Korean youth subculture style is comparatively less unique and bold because Korean youths have a stronger will to dress similarly with other people their age rather than to express their individuality through clothes. Korean people freely express themselves on the highly developed Internet and speak out about social problems, but they do not have many offline associations through which they can achieve real change or any other form of outlet for personal expression. Therefore, it is important to examine the subtle expressions of self through clothing of youths as a tool to understand their culture and values, and create a foundation for fashion design that considers and keeps up with the changing youth culture and demands. Mother cultures of most Korean subcultures are from Europe and the United States, and Korean subculture styles also frequently originate from and are largely influenced by Euro-American countries. However, an examination of changes in contemporary Korean ways of life and values, and characteristics of Korean people, will create a foundation to aid understanding of modern Korean subcultures. There have been studies on Korean subculture styles, but none that have covered recent styles of the 2000s or looked into how they are influenced by their mother cultures. Therefore, this study hopes to hold academic and industrial significance by presenting a new perspective and understanding of Korean youths today and how they make styling choices. A sense of identity and resistance, sexual identity and influence of popular culture are elements that traditionally define subcultures, and this study aims to examine changes of Korean youth subcultures based on these elements.

\section{Contemporary Korean Youth Subcultures}

Subculture refers to the culture of a minority, that is, a specific social class or group that is not part of mainstream popular culture, and youth subculture refers to a subculture of youths, or young people from their 
teenage years to twenties, when they are free, independent and single. Studies, books, newspapers and the Internet were searched for the most recent Korean youth subcultures using key words related to subcultures; subculture, youths, similarity, youth styles, student culture, resistance of youths; and the results were narrowed based on analysis by fashion researchers. The result was an extraction of five Korean youth subcultures - Hip hoppers, skateboarders, clubbers, nightclubbers and riders - and the following is a brief explanation of each of the cultures, based on literary research, direct observations and in-depth interviews with members of each of the subcultures in their own element, such as the clubs they hang out in and spots they get together at, conducted from January to February of 2009.

Hip hoppers listen to and dance to hip hop music. Their activities include DJing, rapping, b-boying and graffiti, and they prefer colorful, comfortable clothes. B-boying is the term used to refer to the dance of b-boys, who traditionally started out as break dancers in the streets of the United States in the early 1970s, and now perform very specific and specialized fields of break dance such as popping and locking (Chung \& Kim \& Park, 2001).

Skateboarders are mostly teenagers who try to escape the pressures of school work through skateboarding. They enjoy the attention and feeling cool, and dress in colorful T-shirts and sneakers.

Clubbers are young people who go to clubs to drink, listen to loud music, dance and socialize with other people their age. An interview with clubbers found that clubbers are interested in having a good time and expressing themselves freely, and like simple, tight clothing styles.

Nightclubbers are different from clubbers because they go to Korean nightclubs, where there is a "booking" system where waiters take women in the club by the hand and walk them to rooms where the men are sitting. The women sit, talk and drink. They may get up if they want to and get booked to another room. It is similar to speed dating in Europe and the United States. Nightclubbers interviewed said it was important for men to look rich and women to look sexy.

Riders are young people, mostly men, who ride motorcycles late at night. They normally ride in groups and ride fast, ignoring traffic laws. They like the speed and attention, but are cautious about safety and dress in safety gear and rider jackets.

\section{Korean Youth Subcultures Since the 1960s}

Figure 1 shows appearance, disappearance and changes of Korean youth subcultures since the 1960s (Park, 2009). Some subcultures that existed until the 1990s have grown weaker recently. Underground rock culture, which was strong in the 1960s and 1970s, gradually faded away by the 2000s, and street dance, which was an active subculture until the 1990s, has now changed to the more popular b-boy culture. The free style of the 1980s and 1990s has largely changed to a more systematic form of b-boy dance competitions. Electronic music is now a big part of mainstream culture and with even hip hop music being mixed with electronic sounds, reggae culture has become an old and weaker subculture in Korea. Cosupure still exists in Korea, but it is more of an infrequent event than an established subculture, and not many Cosuplayers are regularly active, like they are in Japan.

The position of hip hop culture, which originated from American hip hop, has grown stronger, and elements of hip hop culture can now be seen in popular culture, such as hip hop music. Hip hop culture is a youth subculture that continues to exist and it still maintains values of freedom, but while hip hoppers tried to find their own Korean identity in the 1990s, they now have their own natural and colorful Korean style. Korean hip hoppers prefer natural styles to the baggy styles of African Americans that were worn before, and neat baseball caps are a more important style code than big gold accessories of the past. A baggy style that imitated the skateboarder styles of Euro-American skateboarders were the major trend of skateboarders until the 1990s, but now skateboarders pursue a more natural silhouette, too. Skateboarding is another Korean culture that originated from the American skateboarding culture. It used to value professional sports and fashion, but now new values of rebelling against the academic-focused lifestyle of Korean students and wanting to stand out are additional important values. Therefore, they do not wear the same styles as other skateboarders but wear styles to express their own individuality. Some skateboarders even wear skinny jeans when they skateboard.

\section{Insert Figure 1 Here}

Additional Korean youth subcultures that were discovered through this study were clubbers, nightclubbers and riders. Clubbing was introduced from the United States, but only recently started to boom in Korea, and is a nightlife culture through which youths express resistance against restraints of daily life including academic pressures they are put under from a very early age and older generations (Chu \& Lee \& Lee, 2003). Nightclubbing was originally a discotheque culture largely influenced by the American clubbing culture of the 1970s and 1980s, before it changed into a more Koreanized culture with booking. Nightclubbers also want to 
break away from the routines and restraints of daily life, but nightclubs are a more Korean cultural space that reinterprets the foreign club culture. Development of the riders subculture influenced by the biker gangs of the United States recently accelerated with the development of online rider clubs on the Internet. Riding motorcycles is still a minority culture today, but riders now meet other riders through the Internet and ride in groups.

\section{Similarities of and Differences Between Subcultures and their Mother Cultures}

All Korean youth subcultures of the 2000s have a mother culture. A mother culture is a larger culture or a culture of the past that influenced a current culture or from which a current culture was derived. Korea has a short history of hip hop, so the mother culture of hip hoppers is the American hip hop culture that started in the 1970s, and the mother culture of skateboarders is the American skateboarder culture that originally started with American surfers. The mother culture of clubbers is the American club culture that started in the 1960s and boomed in the 1970s. American clubs mostly played disco music in the 1970s, rock music in the 1980s, and changed to electronic music in the 1990s and 2000s. The mother culture of nightclubbers is the Korean discotheque culture of the 1970s and 1980s. The discotheque culture was originally introduced from foreign countries, but Korean discotheques traditionally introduced new people of the opposite sex through waiters, while listening to American music, a practice that has evolved to modern day booking. The mother culture of Korean riders is American biker gangs. Although the U.S. biker culture can include members of any age, not just youth, Korean riders mainly consist of youth members because of the social atmosphere that married men and women should settle down and fold any youthful hobbies they enjoyed before marriage. The similarities of and differences between Korean youth subcultures and their mother cultures are shown in Tables 1 to 5 .

\section{Insert Table 1, Table 2, Table 3, Table 4 and Table 5 Here}

Some subcultures, like clubbers, are very similar to their mother culture, while others have more differences. Nightclubbers have a more Korean element to the discotheque culture and include booking and rooms. Hip hoppers (Figure 2) started from American hip hop (Figure 3), but they now express Korean identity more. Riders (Figure 4) like to ride motorcycles like bikers (Figure 5), but instead of focusing most of their life on riding, they live comparatively regular lives and riding motorcycles is only a part of their lives. American skateboarders have established a popular and more positive image than the past, but Korean skateboarders still have a strong rebel image. They also ride in designated places rather than skateboard wherever they go.

\section{Insert Figure 2, Figure 3, Figure 4 and Figure 5 Here}

\section{Unique Characteristics of Korean Youth Subculture Styles}

\subsection{Sense of Identity}

Korean youth subcultures have strong identities which are expanded through their clothing styles. However, one youth does not necessarily belong to one subculture but may belong to many subcultures. Therefore, they wear strong subculture styles when they are doing a subculture activity but wear normal styles or less extreme styles through which they can still express their identity in everyday life.

The elements of Korean youth subculture style reflect identities of subcultural individuals in a symbolic and implicit way. Korean youths are a materialistic generation and have a strong obsession with appearances. They spend a lot more than older generations, prefer foreign brands, place importance on looks, keep up with new trends, and express their identity through fashionable items and appearance (Seo, 2004). However, they prefer styles that can show off their body, face and status rather than styles that are stylish in themselves. Accessories are not a big part of Korean youth subculture styles, but they do normally wear one or two expensive items. Youths say that brand and price are not important, but in reality tend to wear famous designer jeans or expensive items. Through such items, they create an important status for themselves and not only feel a sense of belonging to a certain subculture, but express their unique selves, too. Korean youths tend to have a stronger desire to express their own individual styles because it takes longer for them to become financially independent from their parents compared to youths of other countries.

The major style codes of Korean youth subcultures are general fashion items that have symbolic significance. For example, wearing a baseball hat to the side is stylish but reflects the unique mind of hip hoppers.

Korean youths traditionally have a strong groupist tendency, and are extremely patriotic especially when watching sports, and this Korean identity reflects in subculture styles, too. The mother culture of Korean hip hop is American hip hop, but Korean hip hoppers wear Korean colors, Korean flag prints, and slimmer styles. 


\subsection{Resistance}

Korean subcultures all resist against the older generation and oppressive social atmosphere, and desire an abundant and fun personal life. Living in an unstable society compared to their elders, Korean youths have a large preference for stable jobs such as working at a large company or being a civil servant. Youths resist against the conservative social culture, but still prefer visually comforting colors and thus generally wear neutral colors such as black, white or gray, and use basic colors like blue and red to add a pop of color to their outfits. Subculture styles are a good tool of resistance for Korean youths, who have strong pressures to conform and succeed because of the social atmosphere that is hard on those who are different, and have no other outlet of effective resistance and expression against society.

Mainstream youth culture in Korea includes karaoke rooms, online game and coffee shops, through which youths seek to relieve stress, a sense of belonging and experience Euro-America culture, which they admire and are curious about (Kim, 2002). Korean youth subcultures seek fun and youthfulness like youth subcultures of other countries, but especially aim to escape from daily life through nightlife or rebel and feel cool and different through unique sports, and create strong subcultures by spending most of their time with other members of the same subculture. However, Korean youths subconsciously pursue stability, so even if they pursue a differentiated culture from mainstream culture, they tend to choose styles that are not largely different from mainstream trends. For example, youths who belong to subcultures may choose to wear unique colored sunglasses or bold accessories but they will wear them with skinny jeans that are now in fashion. Riders wear symbolic style items of their mother culture, biker gangs, but choose styles that are less strong and decorative.

\subsection{Sexual Identity}

Subculture styles in the past traditionally had strong masculine tendencies because most subcultures were formed by men and mostly men rebelled against upper social classes (Leblanc, 2002), but subculture styles today are not necessarily masculine because new subcultures include those that are formed mostly by women. The interviews showed that youths today are more sensitive and artistic than the past and place more importance on personal satisfaction than social recognition. Therefore, feminine tendencies such as slim silhouettes and feminine colors that do not necessarily have a strong edge like masculine black leather jackets have grown stronger.

Subculture styles in Korea especially do not lean towards one gender, but are divided to masculine styles for men and feminine styles for women. Perhaps because of the traditional Confucian ideas of Korea that value family and the role of each person in society, Koreans have a strong desire to fit in, and the roles of men and women are more clearly divided than western countries (Kim \& Song, 2007). Women's subculture styles are generally tight and feminine, and men subculture styles include masculine colors and simple clothes.

The clearly divided sexual identity of subculture styles is apparent through the styles of nightclubbers. Men show off their wealth and status through simple clothes and expensive belts, while women show off beauty by wearing feminine colors and short skirts.

\subsection{Influences of Popular Culture}

Rock ' $n$ ' roll, music and culture solely for youths, appeared in the 1950s when youth subculture first started to emerge, and many subcultures and subculture styles were created based on popular music for youths (Chang, 1994), but today, many different youth music genres exist, and many types of youth cultures also exist, including sports, games and nightlife. Thus, youth subcultures today are affected not only by popular music but other elements of popular culture, and these effects are expressed in subculture styles.

Korean youths like European and American things, and want to become more adult-like and have adult responsibilities. They pursue the comfortable style and image of the United States, and are especially influenced by international popular culture, including American pop music. Therefore, they currently like to wear T-shirts, jeans and sneakers like American youths, and natural materials like cotton, denim and knits.

Clubbers are especially influenced by popular culture. The American club culture has become more sexy and casual compared to the past, and Korean clubbers have caught on, wearing modern and simple styles as opposed to exaggerated decorative styles.

\section{Youth Subculture Styles as a Reflection of Society and the Younger Generation}

Korean youth subculture styles have evolved and changed together with social changes over time, and will continue to change in the future. Youths want to live independently and have fun, but they feel that the social system does not allow them to get what they want. Extreme social pressure is applied to Korean youths to excel in studies and work, and contribute to society. Only the fittest in terms of academics and skills can survive, and 
wealth is another important factor in a modern materialistic society. Youths feel the older generation put them in this pressured situation, yet do not understand young people because they are from a different social era. This is why Korea youth subcultures pursue symbols of uniqueness that differentiate themselves from other generations and the masses, and symbols of wealth and status in their styles. Nevertheless, instead of standing out too much they prefer simple and quite conservative styles compared to subculture styles of other countries because of their basic need to fit in and be accepted, which comes from their groupist side, instilled through a Korean upbringing. Korean youth subculture styles reflect the complex values of youths, and is a useful index showing the mind of youths today and possible trends of the future Korean youth fashion market, as members of subcultures have an effect on mainstream youths and culture.

\section{References}

Chang, M.S. (1994). A study on rock ' $n$ ' roll fashion. Seoul: Ewha Women's University Graduate School Master's degree thesis.

Chu, H., \& Lee, H.,Y., \& Lee, J.B. (2003). An analytical study on education interests of Korean parents. Seoul: Korea Educational Development Center.

Chung, H.S., \& Kim, S.Y., and Park, K.S. (2001). A study on characteristics of hip hop fashion in relation to the cultural characteristics of hip hop. The Costume Culture Association Journal, 9 (5), 747-758.

Kim, H.R., \& Song, B. (2007). Modern Korean society - Its development and prospect. Berkely: Institute of East Asian Studies.

Kim, S.H. (2007). Values of Korean youths. Seoul: Korean Society Research Center.

Leblanc, L. (2002). Pretty in punk - Girls'gender resistance in a boys'subculture. Piscataway, New Jersey: Rutgers University Press.

Park, J. (2009). A comparative study on clothing styles of Korean and Japanese youth subcultures during the 2000s. Seoul: Seoul National University Graduate School Doctorate Degree Thesis.

Table 1. Similarities of and differences between the Korean hip hop subculture and its mother culture

\begin{tabular}{|c|c|c|}
\hline \multirow{2}{*}{ Category } & Subculture & Mother culture \\
\hline & Hip hop & American hip hop \\
\hline \multirow{2}{*}{$\begin{array}{c}\text { Common } \\
\text { points }\end{array}$} & \multicolumn{2}{|c|}{-Culture of youths who enjoy hip hop music } \\
\hline & \multicolumn{2}{|c|}{ •Pursues values of freedom, equality and fun } \\
\hline \multirow[t]{2}{*}{ Differences } & $\begin{array}{l}\text {-Incorporates Korean style elements } \\
\text { such as the Korean flag in clothes }\end{array}$ & $\begin{array}{l}\text {-Incorporates styles that show roots of } \\
\text { hip hop such as African and American } \\
\text { styles in clothes }\end{array}$ \\
\hline & $\begin{array}{l}\text {-Prefers music that includes both } \\
\text { rap and melody }\end{array}$ & -Prefers rap-focused music \\
\hline
\end{tabular}

Table 2. Similarities of and differences between the Korean skateboarding subculture and its mother culture

\begin{tabular}{|c|c|c|}
\hline \multirow{2}{*}{ Category } & Subculture & Mother culture \\
\hline & Skateboarding & American skateboarding \\
\hline \multirow{2}{*}{$\begin{array}{c}\text { Common } \\
\text { points }\end{array}$} & \multicolumn{2}{|l|}{ Most skateboarders are male teenagers } \\
\hline & \multicolumn{2}{|l|}{ Pursue a cool image } \\
\hline \multirow{2}{*}{ Differences } & Strong rebellious image & $\begin{array}{l}\text { Now establish a popular and positive } \\
\text { image }\end{array}$ \\
\hline & $\begin{array}{l}\text { Do not skateboard in everyday life } \\
\text { but ride in skateboarding areas }\end{array}$ & $\begin{array}{l}\text { Use skateboards as a way of getting } \\
\text { around in daily life }\end{array}$ \\
\hline
\end{tabular}

Table 3. Similarities of and differences between the Korean clubbing subculture and its mother culture

\begin{tabular}{|c|c|c|}
\hline \multirow{2}{*}{ Category } & Subculture & Mother culture \\
\hline & Clubbing & American clubbing \\
\hline \multirow{2}{*}{$\begin{array}{l}\text { Common } \\
\text { points }\end{array}$} & \multicolumn{2}{|c|}{-Clubs in the 2000s mostly play electronic music } \\
\hline & \multicolumn{2}{|c|}{$\begin{array}{l}\text { - Clubbers may only enter clubs if they are dressed stylishly, and style is an } \\
\text { important cultural element }\end{array}$} \\
\hline Differences & $\begin{array}{l}\text {-Age of clubbers generally lower } \\
\text { than the United States }\end{array}$ & -People of various ages go to clubs \\
\hline
\end{tabular}


Table 4. Similarities of and differences between the Korean nightclubbing subculture and its mother culture

\begin{tabular}{|c|c|c|}
\hline \multirow{2}{*}{ Category } & Subculture & Mother culture \\
\hline & Nightclubbing & Discotheque \\
\hline \multirow{2}{*}{$\begin{array}{l}\text { Common } \\
\text { points }\end{array}$} & \multicolumn{2}{|c|}{-A dancing culture where youths dance to popular music } \\
\hline & \multicolumn{2}{|c|}{ - Youths meet members of the opposite sex } \\
\hline \multirow{2}{*}{ Differences } & $\begin{array}{l}\text { - Booking system exists through } \\
\text { which people are introduced to } \\
\text { members of the opposite sex }\end{array}$ & -No booking system \\
\hline & $\begin{array}{l}\text {-Men usually get rooms and women } \\
\text { get tables }\end{array}$ & -No rooms \\
\hline
\end{tabular}

Table 5. Similarities of and differences between the Korean riding subculture and its mother culture

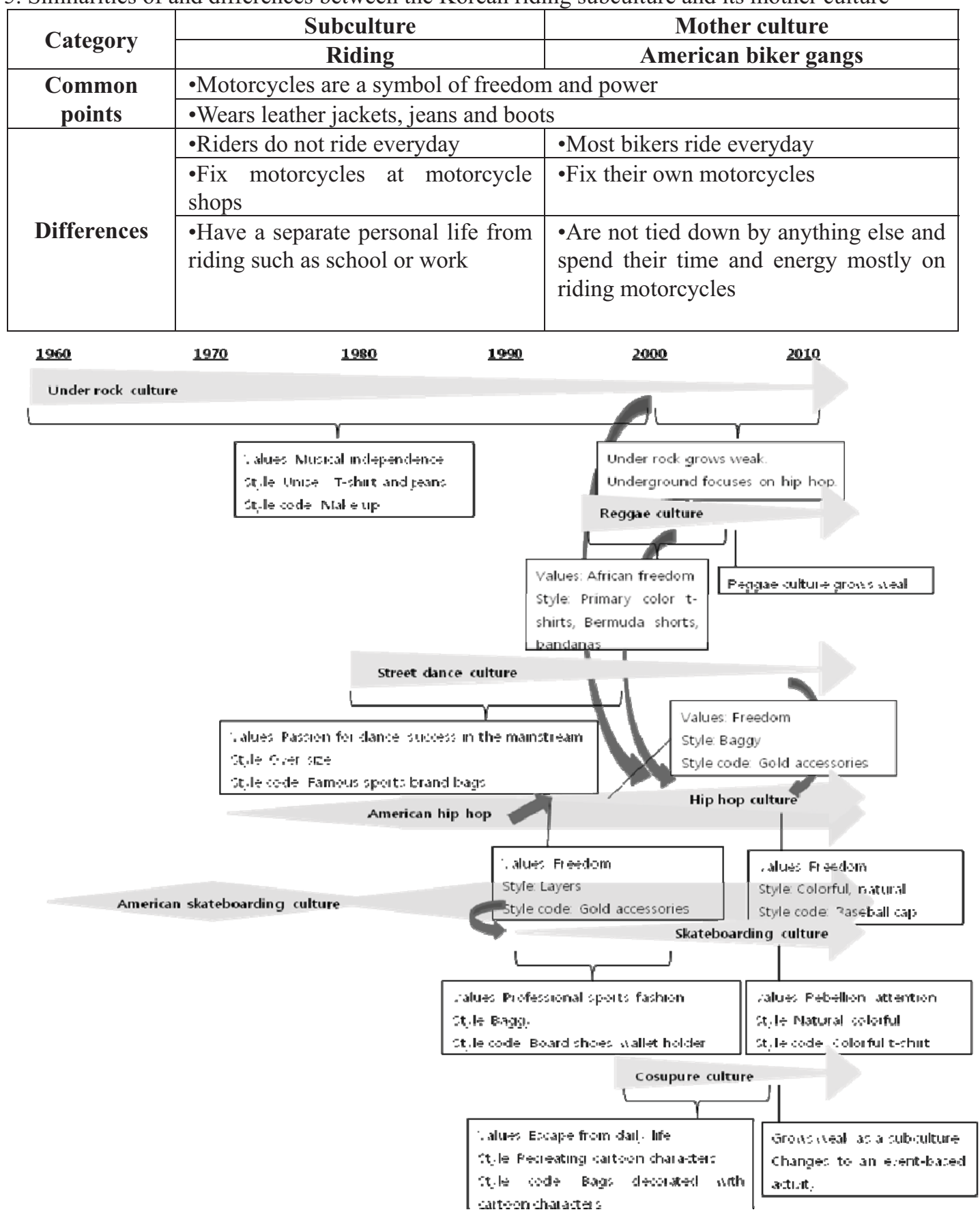




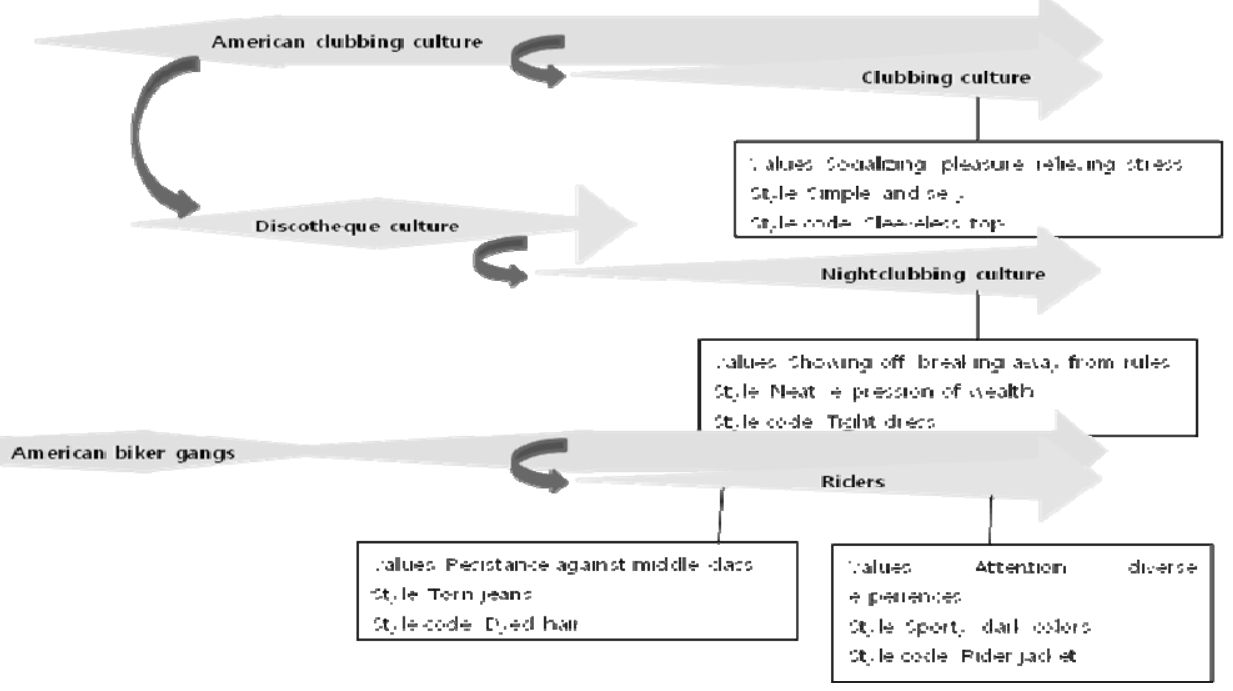

Figure 1. Korean youth subcultures since the 1960s

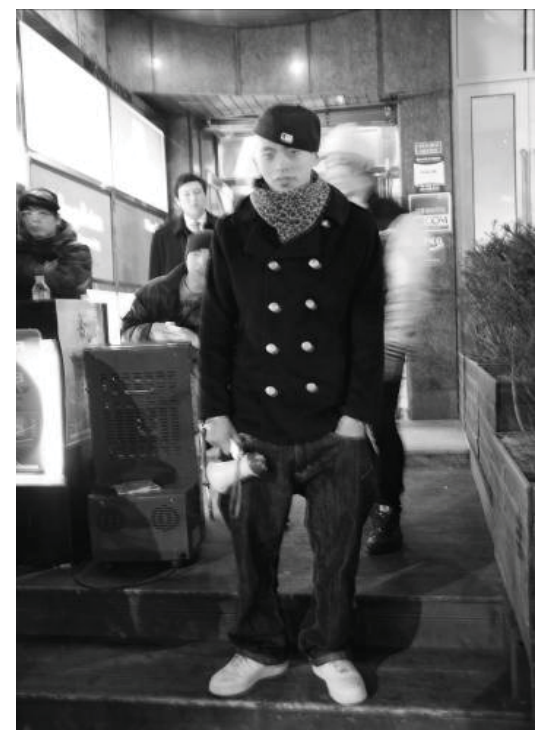

Figure 2. Korean hiphopper, photographed at Hongik University, Seoul, February, 2009

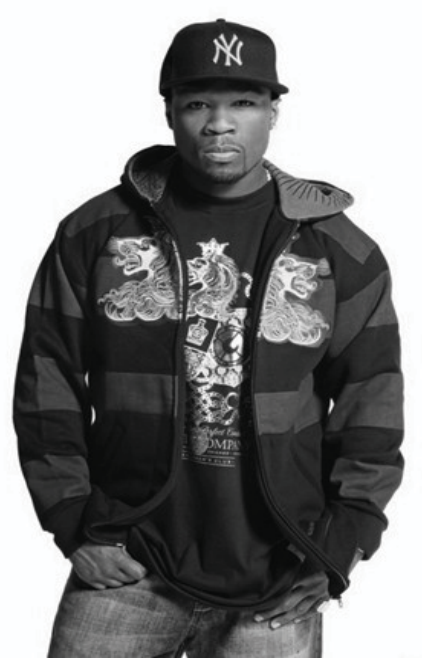

Figure 3. American hiphopper; rapper 50 Cent, 2009. <http://www.50cent.com/photos $>$ (Date of access: 02.12.2009) 


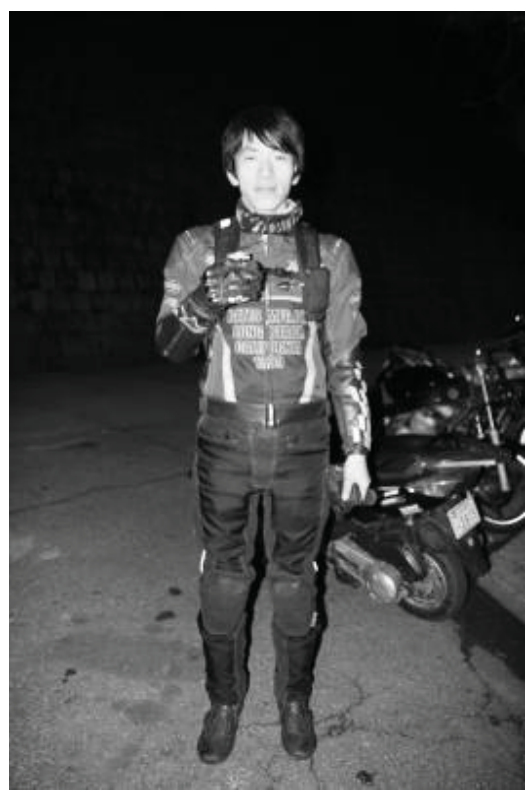

Figure 4. Korean rider, photographed at Namsan Baekbum Park, Seoul, February, 2009

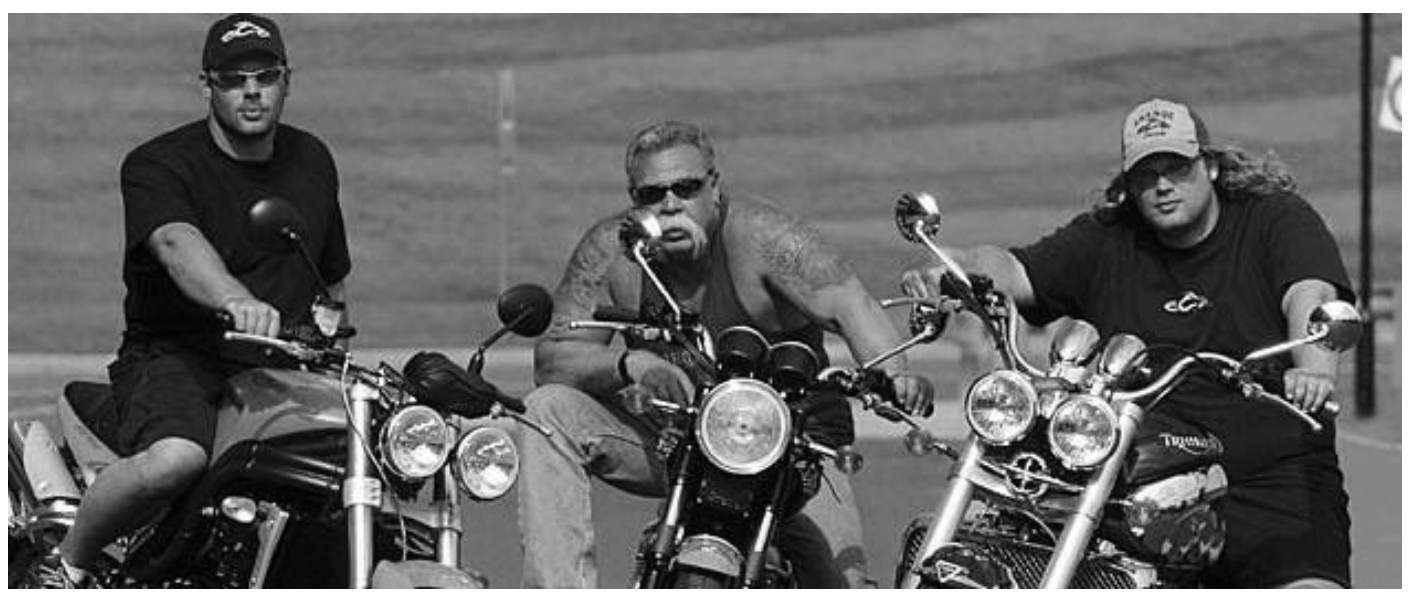

Figure 5. American rider; Cast of reality TV show “American Chopper," 2009. <http://www.discovery channel.co.uk/web/american-chopper> (Date of access: 02.12.2009) 